\title{
Alkaloid levels in a species of low larkspur and their stability in rumen fluid
}

\author{
WALTER MAJAK
}

Author is toxic plant biochemist, Agriculture Canada Research Station, 3015 Ord Road, Kamloops, B.C. V2B8A9.

\begin{abstract}
A survey on the levels of the neurotoxic diterpenoid alkaloid methyllycaconitine (MLA) in low larkspur (Delphinium nuttallianum Pritz.) was conducted at rangeland sites in southern British Columbia. Freeze-dried plant samples representing vegetative, flower bud, and bloom stages of growth over 4 growing seasons were analyzed for MLA by high pressure liquid chromatography (HPLC). Differences in MLA concentration were found between sites $(P<0.01)$ and between stages of growth $(P<0.001)$ but not between years $(P>0.2)$. The vegetative stages of growth yielded the highest levels of MLA, approaching $1 \%$ of the dry matter at 1 site. On average, the reproductive stages of growth yielded half the amount of MLA as the vegetative stages. Differences in MLA levels between sites could not be attributed to the elevation or the weather during the growing season. It is suggested that topoedaphic effects may have an impact on low larkspur growth and toxicity. Preliminary results are also reported on the stability of MLA in bovine rumen contents. The alkaloid is not readily hydrolyzed in rumen contents and therefore is probably not detoxified by this pathway.
\end{abstract}

Key Words: Delphinium nuttallianum, D. menziesii, neurotoxic alkaloids, methyllycaconitine, rumen microbes, cattle poisoning

In North America, plants of the genus Delphinium are conveniently divided into 2 groups based on their height at maturity: the tall larkspurs and the low larkspurs, growing to an average height of 1 to $2 \mathrm{~m}$ and less than $1 \mathrm{~m}$, respectively (Kingsbury 1964). Consumption of tall larkspur ( $D$. barbeyi Huth or $D$. occidentale $\mathrm{S}$. Wats) is the major cause of cattle poisoning on subalpine mountain rangelands in the western U.S. (Neilson and Ralphs 1988). Unlike the tall larkspurs which are climax species, the ephemeral low larkspurs ( $D$. menziesii DC., D. bicolor Nutt., or D. nuttallianum Pritz.) begin their growth in early spring at lower elevations, often before the flush of grasses, when they become readily available to livestock (Looman et al. 1983, James et al. 1980). Low larkspur is more palatable to cattle at early stages of growth but the palatability of tall larkspur increases with advancing stages of growth (Pfister et al. 1988).

The neurotoxic diterpenoid alkaloid methyllycaconitine (MLA) has been identified as the major alkaloid in 3 species of low larkspur: ( $D$. nuttallianum, D. menziesii, and D. bicolor) (Majak et al. 1987, Sun et al. 1992, Kulanthaivel et al. 1986). MLA is also the major toxic alkaloid in 3 species of tall larkspur: D. brownii Rybd., D. barbeyi, and D. glaucescens Wats (Aiyar et al. 1979, Pelletier et al. 1989, Manners et al. 1992). MLA is a potent neuromuscular blocking agent in cattle (Nation et al. 1982) and is probably one of the most toxic alkaloids in rangeland larkspur (Olsen and Manners 1989, Manners et al. 1992). Two minor alkaloids, nudicauline and

\footnotetext{
The author gratefully acknowledges the technical assistance of Ruth McDiarmid and the statistical analyses conducted by John Hall. A.L. van Ryswyk provided site descriptions. The author thanks Michael Benn and Robert Ogilvie for helpful comments on the manuscript.

Manuscript accepted 7 June 1992.
}

deacetylnudicauline, have not been tested for toxicity but they differ from MLA only at the $\mathrm{C}_{14}$ substitution: methoxyl, acetate, and free hydroxyl for MLA, nudicauline, and deacetyl nudicauline, respectively. Most importantly, they all contain the ester function at $\mathbf{C}_{4}$ which is essential for neuromuscular activity (Aiyar et al. 1979). These MLA congeners have also been detected in $D$. nutallianum (Bai et al. 1989), D. menziesii (Sun et al. 1992), and $D$. barbeyi (Pelletier et al. 1989).

A number of different approaches have been used for protecting animals from tall larkspur poisoning, including the use of herbicides. However, some of the most effective chemical agents are now restricted or unavailable (Ralphs and Turner 1989). Training cattle to avoid consumption of tall larkspur is also possible but the conditioned aversion acquired in controlled environments can be lost under field conditions (Ralphs 1992). The seasonal variation in the total alkaloid content of larkspur has been extensively examined in relation to palatability, and a "toxic window" has been proposed for $D$. barbeyi to predict the period of maximum susceptibility of cattle to poisoning (Pfister et al. 1988). However, few studies have eludicated the seasonal variation in the concentration of the specific alkaloids of Delphinium. The present study extends a previous one (Majak and Engelsjord 1988) and further elucidates MLA levels in $D$. nuttallianum, especially at earlier, vegetative stages of growth. As well, the hypothesis that MLA levels are affected by the elevation of the Delphinium site is re-examined. Preliminary experiments are reported on the stability and potential for microbial detoxification of MLA in bovine rumen fluid.

\section{Materials and Methods}

Composite samples ( 50 to $200 \mathrm{~g}$ fresh weight, aerial portions) at the vegetative, flower bud, and bloom stages of growth were collected during 1988 to 1991 at the 4 experimental locations (sites 1 to 4) described previously near Kamloops, B.C. (Majak and Engelsjord 1988). Sites 1, 2, and 3 were located in the Artemisia tridentata Nutt., Stipa-Poa and Festuca scabrella Torr. grassland zones, respectively, while site 4 was in a transition zone between the Pseudotsuga menziesii (Mirbel) Franco forest zone and the $F$. scabrella upper grassland zone. Low larkspur at the mature pod stage of development was not abundant owing to the low moisture conditions of the late spring, so these plants were not collected. As well, plants were not available at sites 2 and 3 during 1990-91. Samples were usually obtained once per week but the number of samples at each stage of growth varied with site and year depending on the duration of the phenological stage. When larkspur plants became elongated and stemmy during the bloom stage, the upper $20 \mathrm{~cm}$ of the shoot, containing most of the leaves and the inflorescence, was excised for analysis. Larkspur samples, stored at $-20^{\circ}$ C, were freeze-dried and analyzed for MLA by HPLC as described previously (Majak and Engelsjord 1988, Majak et al. 1987). MLA concentrations were expressed on the basis of freeze-dried sample weights. The effects of years, 4 sites, and 3 stages of growth $(n=79)$ on MLA concentration were evaluated by analysis of variance 
using SAS GLM (Freund and Littel 1981).

In addition to sites 1 to 4 , that ranged in elevation from 350 to $975 \mathrm{~m}$, larkspur samples $(\mathrm{n}=7)$, predominantly at the full bloom stage of growth, were also collected during 1988 at 3 montane locations near Kamloops, B.C. (site 5) and near Ashcroft, B.C. (sites 6 and 7). Site 5, on Opax Hill, was situated in a semi-open area of a Douglas fir (Pseudotsuga menziesii)-pinegrass (Calamagrostis rubescens Buckl.) community. Sites 6 and 7 were located on Cornwall Hills. Site 6 was situated in a grassland community predominated by Stipa spp. and the surrounding forest contained aspen (Populus spp.), willow (Salix spp.), and Douglas fir. Site 7 was in a sedge (Carex spp.)-containing upper grassland community and the surrounding forest consisted of spruce (Picea engelmanii Parry.), lodgepole pine (Pinus contorta Dougl.), and willow. Larkspur samples were collected at each montane site on 2 or 3 different dates. The soil classifications (Agriculture Canada 1987) and elevations of the new sites are as follows:

Site 5: Dark Gray Chernozem (Boralific Haploboroll); coarse loamy, mixed, cool, sub-humid; strongly sloping SSE, shallow $(20$ to $30 \mathrm{~cm}$ ) lithic, stony, rocky phases; $1,220 \mathrm{~m}$ elevation.

Site 6: Melanic Brunisol (Mollic Eutrocrept); coarse loamy over sandy skeletal, mixed, neutral, cold, subhumid; very strong sloping SW, lithic exceedingly stony phases; $1,370 \mathrm{~m}$ elevation.

Site 7: Melanic Brunisol (Mollic Eutrocrept); coarse loamy over sandy skeletal, mixed, neutral, cold, subhumid, extremely sloping S, lithic, exceedingly stony phases, $1,815 \mathrm{~m}$ elevation. All 7 sites occur in grassland vegetation areas either in continuous grassland zones (Sites 1 and 3) or as topoedaphic outliers within forested areas (sites 2 and 4 to 7 ).

MLA incubations in rumen fluid were conducted as follows: Rumen contents were obtained from 2 ruminally fistulated Hereford steers fed corn silage and 2 Jersey-Hereford cows fed alfalfa hay. The rumen contents were strained through a single layer of cheesecloth into a preheated Thermos flask. Aliquots of the rumen fluid $(50 \mathrm{ml})$ were combined with free base extracts of $D$. nut tallianum prepared as described previously (Majak et al. 1987) to give a final MLA concentration of $150 \mathrm{ppm}$. The incubations were handled anaerobically at $39^{\circ} \mathrm{C}$ and subsamples $(1 \mathrm{ml})$, obtained at $15 \mathrm{~min}$ and 3 hours, were acidified with $2.5 \mathrm{ml} 4 \mathrm{~N} \mathrm{H}_{2} \mathrm{SO}_{4}$ and centrifuged at $40,000 \times \mathrm{g}$ for $10 \mathrm{~min}$ at $0^{\circ} \mathrm{C}$. The supernatant was decanted, extracted for free bases, and the MLA concentration in rumen fluid was determined by HPLC.

\section{Results and Discussion}

In agreement with our earlier studies (Majak and Engelsjord 1988), there were significant differences in MLA concentrations between sites $(P<0.01)$ and between stages of growth $(P<0.001)$ but not between years $(P>0.2)$. In the present study there were no significant interactions. The highest levels of MLA were detected at vegetative stages of growth (Fig. 1) when MLA levels ranged from 0.14 to $0.87 \%$ and the average concentration was $0.37 \%$ MLA $(S E=0.02)$. The average MLA concentration at the vegetative stage was almost twice as great as the MLA averages during the flower bud $(0.21 \%)$ or bloom $(0.20 \%)$ stages of growth. Similar levels of MLA $(0.18$ to $0.21 \%)$ were reported previously for the reproductive stages of growth of $D$. nuttallianum but the earlier study did not examine the alkaloids at the vegetative stage (Majak and Engelsjord 1988).

Given intravenously, MLA was acutely toxic to cattle at 1 $\mathrm{mg} / \mathrm{kg}$ body weight (Nation et al. 1982). Therefore, if the plant contained $0.5 \% \mathrm{MLA}$, as little as $100 \mathrm{~g}$ dry matter of larkspur could be toxic to a $500 \mathrm{~kg}$ animal. It is clear, therefore, that $D$. nuttallianum is most hazardous to livestock at early, vegetative stages of

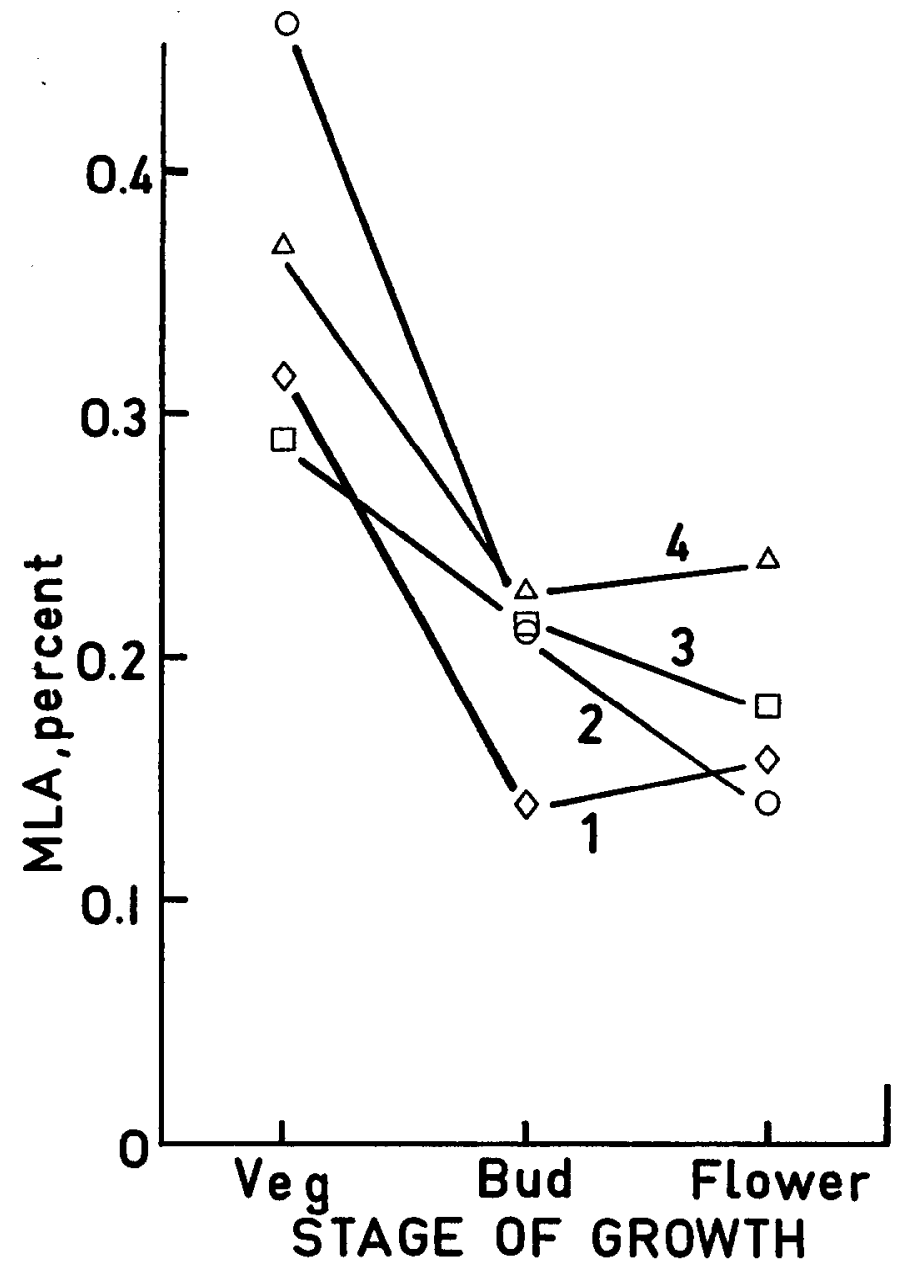

Fig. 1. Changes in methyllycaconitine (MLA) levels in aerial growth of low larkspur at 4 sites, data averaged over 4 years and expressed on a dry matter basis. $S E=0.04$. VEG $=$ vegetative stage of growth; $B U D=$ flower bud stage of growth.

growth (Fig. 1), especially if it emerges before the flush of grasses. Low larkspur forage is also more palatable to cattle at early stages of growth (James et al. 1980, Majak and Engelsjord 1988).

A sample of $D$. menziesii at full flower, collected near Victoria, B.C. (Sun et al. 1992), contained 0.23\% MLA as determined by HPLC and it is possible that this species may contain higher levels of MLA during vegetative stages of growth. However, all previous reports of alkaloid toxicity of $D$. menziesii have been based on incorrect taxonomy and nomenclature (Kingsbury 1964, Ewan 1945). Delphinium menziesii is strictly coastal, occurring west of the Coast and Cascade ranges from southwestern British Columbia to northern California (Hitchcock et al. 1964, Brayshaw 1989). All of the previously published references to poisoning by $D$. menziesii are based on work conducted on plants from outside the geographic range of this plant. In contrast, $D$. nuttallianum occurs east of the Coast and Cascade mountains from British Columbia and southwestern Alberta, southward to northern California, Arizona, and down the Rocky Mountains through Montana, Wyoming, Colorado, and east to Nebraska (R.T. Ogilvie, personal communication).

Previously we reported that higher levels of MLA were associated with $D$. nuttallianum sites located at higher elevations. During 1986-87, for example, the average MLA level was $0.25 \%$ $(\mathrm{SE}=0.02)$ at 900 to $975 \mathrm{~m}$ but at $350 \mathrm{~m}$ it was $0.15 \%$ MLA $(\mathrm{SE}=0.01)$. However, there was a significant site $\times$ year interaction 
and a relationship to elevation was clearly discerned in 1987 but not in 1986 (Majak and Engelsjord 1988). When the overall means for MLA were compared in the present study, differences between sites were not associated with elevation: site $4(0.29 \%$ MLA, elevation $975 \mathrm{~m})$ and site $2(0.30 \%$ MLA, elevation $350 \mathrm{~m})$ differed from site $1(0.20 \%$ MLA, elevation $350 \mathrm{~m})$ but site $3(0.25 \%$ MLA, elevation $900 \mathrm{~m}$ ) was intermediate in alkaloid concentration ( $S E=0.02)$. A significant difference between site $1(0.15 \%$ MLA) and site $4(0.23 \%$ MLA) was also detected when the data were analyzed at the reproductive stages of growth ( $S E=0.01)$. In this analysis, however, site 2 at $0.19 \%$ MLA was indistinguishable from site 3 at $0.20 \%$ MLA.

To further assess the effect of elevation on MLA levels in $D$. nuttallianum, larkspur samples were collected at 3 montane locations including 2 subalpine sites in the southern interior of British Columbia. Sites 5 to 7 exceeded the elevation of site 4 by 400 to 800 $\mathrm{m}$ but the MLA levels (range 0.09 to $0.32 \%$; mean $0.18 \%, \mathrm{SE}=0.04$ ) at the montane sites were not exceptional. Thus, elevation alone cannot explain the variation in MLA concentration between sites. Site differences might be related to topoedaphic conditions that contribute to soil drought and affect the ephemeral cycle of $D$. nuttallianum. Water stress has been shown to increase alkaloid levels in a number of plants (Gershenzon 1984, Majak et al. 1979).

No changes in MLA level were detected from year to year. Therefore, it is unlikely that MLA concentrations are significantly affected by the normal variation of weather during the growth of low larkspur.

The esterified chromophore of MLA, the (methylsuccinimido)anthranoyl function, permits rapid visualization of the alkaloid on HPLC by ultra-violet detection at $210 \mathrm{~nm}$ (Majak et al. 1987). The alkaloid is stable at neutral or acid $\mathrm{pH}$; but at $\mathrm{pH} 9$, the succinimide ring is opened as evidenced by the disappearance of the MLA peak and the gradual appearance of a second peak with a shorter retention time. In borate buffer at pH 9, for example, MLA (150 ppm) showed a half-life of approximately 2 hours. At pH 12, the alkaloid peak can also.be obliterated within an hour by the alkaline hydrolysis of the ester linkage and the resultant loss of the chromophore. These chemical studies established the stability of MLA at physiological pH and revealed the pattern of MLA degradation that might be observed during biotic degradation.

However, there was no evidence of MLA degradation when the alkaloid was incubated in rumen fluid from cattle in either diet (Table 1). The average recovery of MLA from rumen fluid supernatant was $66 \%$ (Table 1 ) and an additional $5 \%$ was associated with

Table 1. Stability of MLA when incubated in bovine rumen fluid in vitro.'

\begin{tabular}{lcccc}
\hline \hline Diet & $\mathrm{n}^{2}$ & 0.25 hours & 3.0 hours & Probability \\
\hline $\begin{array}{l}\text { Corn silage } \\
\text { (Zea mays L.) }\end{array}$ & 4 & $109 \pm 20$ & $102 \pm 15$ & $\mathrm{NS}^{3}$ \\
$\begin{array}{l}\text { Alfalfa hay } \\
\text { (Medicago sativa L.) }\end{array}$ & 4 & $87 \pm 7.9$ & $96 \pm 10$ & $\mathrm{NS}$ \\
\hline
\end{tabular}

'MLA, $150 \mathrm{ppm}$, incubated anaerobically at $39^{\circ}$ in $50 \mathrm{ml}$ rumen fluid. Number of incubations per diet.

${ }^{3} \mathrm{MLA}$ concentrations were not significantly different at $3 \mathrm{~h}$

the sedimented particulate fraction. The MLA recovery of $71 \%$ was not as efficient as the recovery of MLA from plant extracts $(>90 \%)$ but the chromatographic evidence did not indicate a loss due to hydrolysis or ring opening and a change in MLA concentration was not detected in vitro (Table 1). These results suggest that the ester function of MLA is stable in the bovine rumen ecosystem and that the bond is protected or unavailable to the microbial esterases that are abundant in the rumen (Gustine et al. 1977). The alkaloids of Delphinium geyeri Greene also appear to be relatively stable in the rumen environment since their total rate of degradation was $<1 \% \mathrm{~h}^{-1}$ (Siemen et al. 1991).

Degradation of MLA through ester hydrolysis is probably not the route of MLA detoxification in the rumen. In agreement, Swick et al. (1983) also concluded that the pyrrolizidine alkaloids of Senecio jacobaea L., which contain cyclic ester functions, were not hydrolyzed and therefore not detoxified in bovine rumen fluid. However, pyrrolizidine alkaloids of Echium plantagineum L. and Heliotropium europaeum L., which contain open chain esters, were detoxified by hydrolysis in ovine rumen fluid (Cheeke 1989). Thus the configuration of the ester function may well determine the susceptibility of the alkaloid to microbial hydrolysis.

In summary, site and stage of growth are the most important factors affecting the levels of MLA in D. nuttallianum. The vegetative stage of growth yielded the highest concentration of the neurotoxin and consequently it presents the greatest risk to grazing livestock. MLA appears to be stable in bovine rumen fluid since the alkaloid was not hydrolyzed in vitro.

\section{Literature Cited}

Agriculture Canada Expert Committee on Soil Survey. 1987. The Canada system of soil classification. 2nd ed. Agr. Can. Pub. 1646, Ottawa.

Alyar, V.N., M.H. Benn, T. Hanna, J. Jacyno, S.H. Roth, and J.L. Wilkens. 1979. The principal toxin of Delphinium brownii Rybd. and its mode of action. Experientia 35:1367-1368.

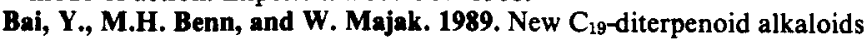
from Delphinium nuttallianum Pritz. Heterocycles 29:1017-1021.

Brayshaw, C. 1989. Buttercups, waterlilies and their relatives in British Columbia. Royal B.C. Museum, Victoria, B.C.

Cheeke, P.R. 1989. Pyrrolizidine alkaloid toxicity and metabolism in laboratory animals and livestock, p. 1-22. In: P.R. Cheeke (ed.), Toxicants of plant origin, Vol. 1 Alkaloids. CRC Press, Boca Raton, Fla.

Ewan, J.A. 1945. A synopsis of the North American species of Delphinium. Univ. Colorado Studies Ser. D. 2:55-242.

Freund, R.J., and R.C. Littell. 1981. SAS for linear models, Guide to ANOVA and GLM procedures. SAS Institute Inc., Cary, N.C.

Gershenzon, J. 1984. Changes in levels of plant secondary metabolites under water and nutrient stress, p. 273-320. In: B.N. Timmerman, C. Steelink, and F.A. Loewus (eds.), Recent advances in phytochemistry, Phytochemical Adaptations to Stress. Plenum Press, N.Y.

Gustine, D.L., B.G. Moyer, P.J. Wangsness, and J.S. Shenk. 1977. Ruminal metabolism of 3-nitropropanoyl-D-glucopyranoses from crownvetch. J. Anim. Sci. 44:1107-1111.

Hitchcock, C.L., A. Cronquist, M. Ownbey, and J.W. Thompson. 1964. Vascular plants of the Pacific Northwest. Part 2: Salicaceae to Saxifragaceae. Univ. Washington Press, Seattle.

James, L.F., R.F. Keeler, A.E. Johnson, M.C. Williams, E.H. Cronin, and J.D. Olsen. 1980. Plants poisonous to livestock in the Western states. Agr. Info. Bull. 415, USDA.

Kingsbury, J.M. 1964. Poisonous plants of the United States and Canada. Prentice-Hall Inc., Englewood Cliffs, N.J.

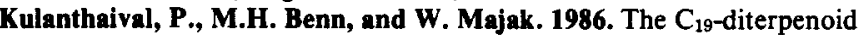
alkaloids of Delphinium bicolor. Phytochemistry 25:1511-1513.

Looman, J., W. Majak, and S. Smoliak, 1983. Stock-poisoning plants of western Canada. Contribution 1982-7E. Agriculture Canada.

Majak, W., and M. Engelsjord. 1988. Levels of a neurotoxic alkaloid in a species of low larkspur. J. Range Manage. 41:224-226.

Majak, W., R.E. McDiarmid, and M.H. Benn. 1987. Isolation and HPLC determination of methyllycaconitine in a species of low larkspur (Delphinium nuttallianum). J. Agr. Food Chem. 35:800-802.

Majak, W., R.E. McDiarmid, T.W. Powell, A.L. van Ryswyk, D.G. Stout, R.J. Williams, R.E. Tucker. 1979. Relationships between alkaloids in reed canarygrass (Phalaris arundinacea), soil moisture and nitrogen fertility. Plant, Cell and Environ. 2:335-340.

Manners, G.D., J.A. Pfister, M.H. Ralphs, K.E. Panter, and J.D. Olsen. 1992. Larkspur chemistry: toxic alkaloids in tall larkspurs. J. Range Manage. 45:63-67.

Nation, P.N., M.H. Benn, S.H. Roth, and J.L. Wilkens. 1982. Clinical signs and studies of the site of action of purified larkspur alkaloid, methyllycaconitine, administered parenterally to calves. Can. Vet. J. 23:264-266. 
Nielson, D.B., and M.H. Ralphs. 1988. Larkspur: economic considerations, p. 119-129. In: L.F. James, M.H. Ralphs, and D.B. Nielson (eds.), The ecology and economic impact of poisonous plants on livestock production. Westview Press, Boulder, Colo.

Olsen, J.D., and G.D. Manners. 1989. Toxicology of diterpenoid alkaloids in rangeland larkspur (Delphinium spp.), p. 291-326. In: P.R. Cheeke (ed.), Toxicants of plant origin, Vol. I Alkaloids. CRC Press Inc., Boca Raton, Fla.

Pelletier, S.W., P. Kulanthaivel, and J.D. Olsen. 1989. Alkaloids of Delphinium barbeyi. Phytochemistry 28:1521-1525.

Pfister, J.A., G.D. Manners, M.H. Ralphs, Z.X. Hong, and M.A. Lane. 1988. Effects of phenology, site, and rumen fill on tall larkspur consumption by cattle. J. Range Manage. 41:509-514.
Ralphs, M.H. 1992. Continued food aversion: training livestock to avoid eating poisonoug plants. J. Range Manage. 45:46-51.

Ralphs, M.H., and D.L. Turner. 1989. Difficulty in controlling duncecap larkspur (Delphinium occidentale). Weed Technol. 3:335-339.

Siemon, R.S., M.F. Raisbeck, and J.W. Waggoner. 1991. Bovine ruminal metabolism of larkspur alkaloids. Abstr. J. Anim. Sci. 69(Suppl. 1):271. Sun, F., M.H. Benn, and W. Majak. 1991. Norditerpenoid alkaloids from Delphinium menziesii DC. Heterocycles 32:1983-1988.

Swick, R.A., P.R. Cheeke, H.S. Ramsdell, and D.R. Buhler. 1983. Effect of sheep rumen fermentation and methane inhibition on the toxicity of Senecio jacobaea. J. Anim. Sci. 56:645-651. 